\title{
Mudanças no consumo de bens culturais no Brasil após a estabilização da moeda
}

\author{
Palavras-chave \\ economia brasileira, \\ estabilização monetária, \\ padrão de consumo, \\ bens culturais. \\ Classificação JEL \\ L82, Z10, Z11 \\ Keywords \\ Brazilian economy, \\ monetary stability, \\ consumption patterns, \\ cultural goods \\ JEL Classification \\ L82, Z10, Z11

Resumo

O objetivo do presente artigo é sugerir explicações para a clara assimetria existente entre, de um lado, a evolução global do consumo das famílias brasileiras após a estabilização da moeda e, de outro, a performance que aí têm três dos chamados "bens culturais": o cinema, a música e o livro. Os dados mostram que, enquanto no primeiro caso temos uma trajetória claramente ascendente, nos três mercados citados, a trajetória é, no melhor dos casos, estável, e na maior parte dos casos, descendente. A explicação sugerida combina três elementos: uma mudança no padrão de consumo de bens duráveis em paralelo com o crescimento e a melhora distributiva, a mudança no tipo de sociabilidade que o novo padrão implicou e fenômenos específicos desses três mercados que elevaram o número de bens substitutos.

Fábio de Sá Earp ${ }^{*}$

Leda Maria Paulani**

\section{Abstract}

The main goal of this paper is to explain the clear asymmetry that exists between the global evolution of Brazilian families' consumption after monetary stability and the performance of three particular cultural goods: movie, music and books. The data show that there is a clear ascendant trajectory in the first case while in the second the movement is in the best case stable and descendent in the most cases. The suggested explanation combines three different elements: a change in the pattern of consumption of durable goods together with a change in income distribution, a change in the type of sociability that the new consumption pattern has provoked, and specific events of these three markets, which raised the number of substituted goods. 


\section{1_Introdução}

Obtida a estabilização da moeda brasileira, em meados de 1994, várias das variáveis macroeconômicas básicas passaram a sentir sua influência. $O$ consumo agregado, por exemplo, encetou uma trajetória claramente ascendente, uma vez ultrapassados os quatro primeiros anos de conturbadas crises financeiras e de política cambial insustentável. Alguns bens em particular, porém, parecem ter ignorado esse movimento, configurando assim uma assimetria entre as suas particulares trajetórias e o movimento geral. Como mostra o gráfico, abaixo, esse é claramente o caso de três dos chamados "bens culturais": o cinema, a música e o livro.

De acordo com o Gráfico 1, a assimetria se dá entre a expansão do consumo global das famílias, que é de $57 \%$, entre 1995 e 2009, e as retrações observadas, no mesmo período, nos gastos das famílias com a compra de ingressos em salas de cinema, ${ }^{1}$ de vendas de livros ao setor privado (que cai 44
\%) e de venda de música gravada (que cai $87 \%$ ). Esse é um fenômeno contraintuitivo, na medida em que se deveria esperar que o consumo crescesse de forma mais homogênea nos diversos setores, particularmente considerando-se que nenhum dos bens em questão tem as características de um bem de Giffen, antes o contrário.

$\mathrm{O}$ fenômeno parece ainda mais interessante tendo em vista que os três bens se enquadram dentro daquilo que se poderia chamar "consumo de bens culturais", o que suscita a hipótese de que outros elementos que não os estritamente econômicos possam estar aqui presentes.

Como se verá a seguir, a explicação aqui apresentada conjuga três elementos, nem todos de extração exclusivamente econômica. De modo resumido, argumentaremos que: a) ocorreu uma mudança no padrão de consumo de massa de bens duráveis no país, em paralelo com o cres-

Gráfico 1_Consumo global das famílias e de bens culturais (1995 = 100)

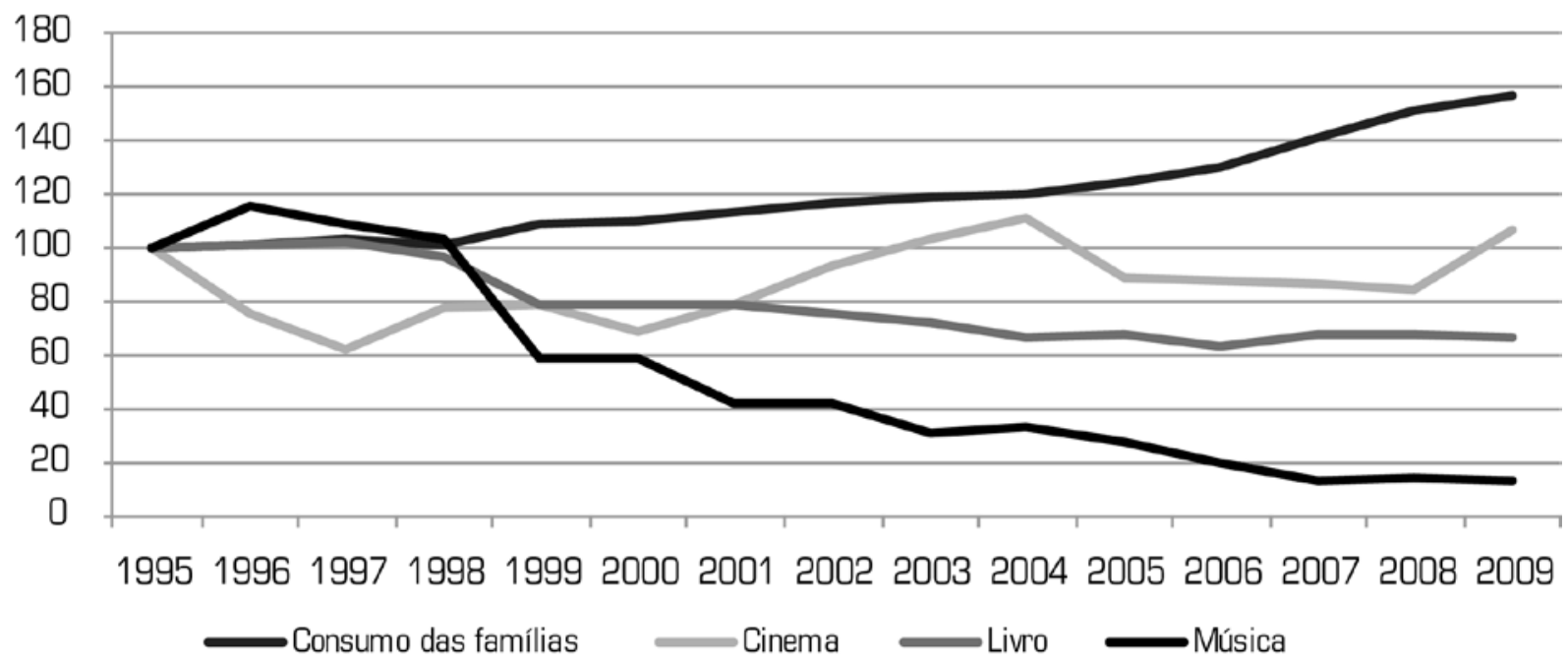

Fontes: Nossa elaboração com base em dados do Ipeadata (consumo das famílias), Filme B (cinema), ABPD (música) e FIPE-CBL/SNEL (livro). Todos os valores foram corrigidos pelo IPCA. 
cimento e a distribuição da renda; b) o novo padrão implicou uma mudança no espaço público de sociabilidade que desviou o interesse dos consumidores para novas atividades propiciadas pela difusão do uso de computadores e da internet; e c) ocorreram fenômenos específicos nos mercados do cinema, do livro e da música gravada, com o aparecimento de bens substitutos que aumentaram o consumo de filmes, material de leitura e música, porém em outros suportes, propiciados pelos dois fenômenos anteriores. As três seções que se seguem desenvolvem esses três argumentos. Uma última seção traz as conclusões.

\section{2_Mudanças na renda e no padrão de consumo}

\section{1_As mudanças na distribuição da renda}

Para desenvolver o primeiro argumento, partimos aqui da hipótese de que a estabilização foi um dos primeiros elementos a promover melhora na distribuição de renda, sendo em seguida combinada com a retomada do crescimento, a partir principalmente de 2004, com o crescimento real do poder de compra do salário mínimo ao longo de todo o período $^{2}$ e com a enorme difusão das políticas de renda compensatória do tipo Bolsa-Família, principalmente a partir de 2003. A fim de mensurar esse fenômeno, adotamos a estratificação social proposta por Quadros (2008, 2010), que utiliza os dados fornecidos pelas PNADs para dividir a população brasileira em cinco grandes categorias: alta classe média, média classe média, baixa classe média, massa trabalhadora e miseráveis. ${ }^{3} \mathrm{O}$ critério utilizado, seguindo o próprio Quadros foi o da classificação por famílias segundo a renda do membro mais bem remunerado. A alta classe média é constituída por aqueles que pertencem a famílias cujo membro melhor remunerado percebe renda mensal igual ou superior a $\mathrm{R} \$ 3.500,00$ sendo pessoas com acesso a melhores serviços de educação, saúde, alimentação, moradia, viagens, cultura, lazer, etc. Por grupo de ocupações, temos aí microempresários, engenheiros, médicos, professores universitários, juristas, diretores de empresas. Dos poucos mais de 91 milhões de indivíduos ocupados no país, em 2009, cerca de 4,9 milhões estavam na alta classe média. Acrescentando-se indivíduos não ocupados, mas com renda e os familiares de todos, encontramos 14,7 milhões de brasileiros em famílias cujo membro mais bem remunerado se encontra nessa faixa de renda, compreendendo $7,7 \%$ da população. Em reais de 2009, deflacionada a série pelo INPC, a renda familiar média dessas pessoas era de $\mathrm{R} \$ 7.119,00 \mathrm{em} 1995$, caindo para $\mathrm{R} \$ 6.199,00 \mathrm{em} 2003$, e novamente caindo em 2007 para $\mathrm{R} \$ 6.140,00 .^{4}$

Em seguida vem a média classe média, constituída por aqueles pertencentes a famílias cujo membro mais bem remunerado percebe vencimentos mensais entre $R \$ 1.750,00 \mathrm{e}$ $\mathrm{R} \$ 3.500,00$. Os principais grupos de ocupação aqui são professores do nível médio, profissionais de segurança pública, militares, enfermeiras e técnicos diversos. O padrão de consumo dessa camada tenta reproduzir o da camada imediatamente superior, ainda que com restrições. Em 2009, existiam 8,4 milhões de indivíduos ocupados nessa faixa de renda; agregando-se indivíduos não ocupados com renda e mais os familiares, chega-se a 25,3 milhões de pessoas (13,2\% da população total). Em 1995, a renda familiar média dessas pessoas era de $\mathrm{R} \$ 2.313,00$, caindo para $\mathrm{R} \$ 1.987,00$ em 2003 e recuperando parte da perda em 2007, quando atingiu $\mathrm{R} \$ 1.869,00$.

A baixa classe média percebe rendimentos mensais declarados entre $\mathrm{R} \$ 750,00$ e R \$1.750,00. As ocupações referem-se a professores do ensino fundamental, auxiliares de escritório, balconistas, auxiliares de enfermagem, motoristas, garçons, recepcionistas, manicures, cabeleireiros, barbeiros e diversos tipos de trabalhadores qualificados. Em 2009, perfaziam 30 milhões de indivíduos ocupados, o que, incluindo desocu- 
pados e familiares, totalizava 74,3 milhões de pessoas $(38,8 \%$ da população total). Em 1995, a renda familiar média desse agregado era de $\mathrm{R} \$ 999,00$, caindo para $\mathrm{R} \$ 930,00 \mathrm{em} 2003$ e recuperando-se parcialmente em 2007, quando atinge $\mathrm{R} \$ 981,00$.

A massa trabalhadora, na estratificação de Quadros, é formada pelos que percebem entre $\mathrm{R} \$ 350,00$ e R $\$ 700,00$ por mês. Compreendia, em 2009, cerca de 30,1 milhões de indivíduos ocupados, praticamente o mesmo número que a baixa classe média. Quando se incluem desocupados e familiares, seu número alcançava 58,8 milhões de brasileiros, cerca de $30,7 \%$ da população total. A renda familiar média dos trabalhadores em 1995 era de $\mathrm{R} \$ 603,00$, caindo para $\mathrm{R} \$ 565,00 \mathrm{em}$ 2003 e recuperando-se parcialmente para $\mathrm{R} \$ 590,00 \mathrm{em} 2007$.

Finalmente, os miseráveis compreendiam aqueles com receitas mensais inferiores a $\mathrm{R} \$ 350,00$ (incluindo-se aí também a camada inferior desse estrato, os indigentes). Em 2009, eram 17,2 milhões de trabalhadores ocupados; incluindo familiares, alcançavam 18,6 milhões de brasileiros, cerca de $9,7 \%$ da população total. Os miseráveis tinham renda familiar média de $\mathrm{R} \$ 286,00 \mathrm{em} 1995$, que caiu para $\mathrm{R} \$ 279,00$ em 2003 e novamente caiu para $\mathrm{R} \$ 276,00 \mathrm{em} 2007$.
Podemos igualmente mostrar como evoluiu o número de pessoas em cada faixa de renda, a partir da estabilização da moeda. Dividimos os dados em dois períodos, um deles de 1995 a 2002, correspondente aos governos de Fernando Henrique Cardoso (FHC), e o outro chegando a 2009, correspondendo, grosso modo, aos governos Lula.

A classe média alta foi reduzida em 2 milhões de pessoas durante os governos de FHC, voltando aproximadamente ao número inicial durante os governos de Lula. A média classe média ficou praticamente estagnada durante os anos FHC, aumentando em quase 6 milhões nos anos Lula. A mais forte variação foi aquela verificada na baixa classe média, que aumentou em 4,1 milhões durante os anos FHC e mais 22,1 milhões nos anos Lula, passando assim de 48,1 milhões de pessoas em 1995 para 74,3 milhões em 2009. Os trabalhadores tiveram aproximadamente o mesmo aumento nos dois governos - 8,2 milhões em FHC e 8,7 milhões em Lula. Já os miseráveis aumentaram em 6,3 milhões em FHC e diminuíram em 24,6 milhões nos governos Lula. Estas mudanças aparecem no gráfico abaixo.

Tabela 1_Número de brasileiros por faixa de renda, segundo o membro mais bem remunerado da família (1995-2009)

\begin{tabular}{|c|c|c|c|c|c|c|}
\hline Faixa de renda & 1995 & 2002 & 2009 & $\begin{array}{l}\text { Variação } \\
\text { 1995-2002 }\end{array}$ & $\begin{array}{l}\text { Variação } \\
\text { २००२-२००९ }\end{array}$ & $\begin{array}{l}\text { Variação } \\
\text { 1995-2009 }\end{array}$ \\
\hline Alta classe média & 14,8 & 12,7 & 14,7 & $-2,1$ & 2,0 & $-0,1$ \\
\hline Média classe média & 19,9 & 19,4 & 25,3 & $-0,5$ & 5,9 & 5,4 \\
\hline Baixa classe média & 48,1 & 52,2 & 74,3 & 4,1 & 22,1 & 26,2 \\
\hline Trabalhadores & 42,3 & 50,1 & 58,8 & 8,2 & 8,7 & 16,5 \\
\hline Miseráveis & 33,7 & 42,0 & 18,6 & 6,3 & $-24,6$ & $-15,1$ \\
\hline Total & 158,8 & 179,4 & 191,7 & 20,6 & 12,3 & 32,9 \\
\hline
\end{tabular}

Fonte: dados Quadros $(2008,2010)$ e Ipeadata, nossa elaboração. 


\section{Gráfico 2_Distribuição da renda (1995-2003-2009)}

Milhôes de brasileiros por faixa de renda

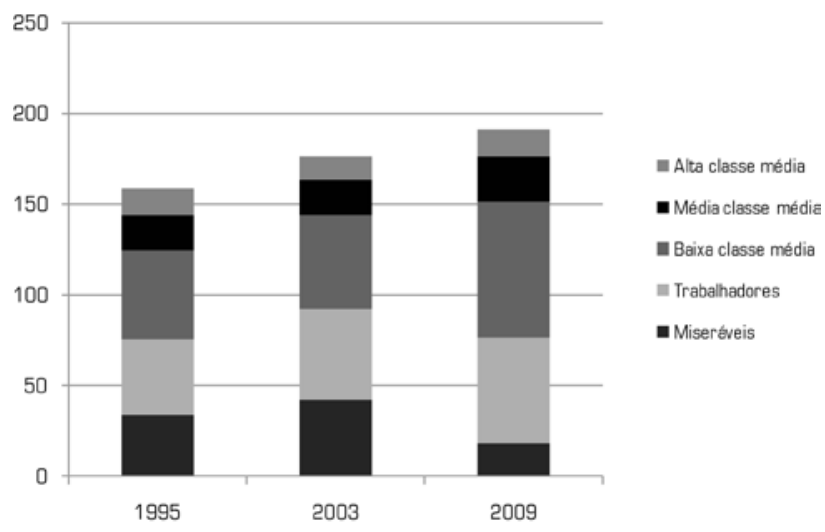

Fonte: Dados: Quadros (2008, 2010), nossa elaboração.

Esses resultados expressam a redução da concentração de renda anteriormente existente. $\mathrm{O}$ índice de Gini ficou praticamente estável entre $1994(0.60)$ e $2002(0,59)$, mas caiu para 0,54 em 2009 (IPEA 2010). Apesar do viés provocado pelo fato de a PNAD, que é a base para o cálculo do índice no Brasil, praticamente não capturar outro tipo de renda que não as rendas do trabalho (vide nota 3), a mudança é suficientemente forte para atestar substantiva transformação no padrão distributivo. Assistimos, portanto, a um importantíssimo processo de mobilidade social durante 0 período, em particular no período de 2002 a 2009, que não poderia deixar de influenciar fortemente o consumo.

\section{2_Mudanças no padrão de consumo de duráveis}

A difusão de bens de consumo duráveis costuma ocorrer em ondas, começando das camadas de renda mais alta e progressivamente se espraiando para os grupos de menor poder aquisitivo. Esse processo foi racionalizado por Matsuyama (2002, p. 1039) da seguinte maneira:
À medida que cresce a renda dos domicílios, expande-se o conjunto dos diferentes tipos de bens que eles consomem, ao invés de observar-se um crescimento no consumo dos bens que já eram anteriormente consumidos. Isto tem importantes implicações. Em primeiro lugar, o tamanho do mercado para cada bem depende não apenas do número de domicílios, mas do número de domicílios que pode arcar com a aquisição de cada um deles. Em segundo lugar, quando os preços dos bens de primeira necessidade caem, a demanda pelos bens de prioridade inferior sobe. Ou seja, existem complementaridades de demanda entre bens de primeira necessidade e bens de prioridade mais reduzida. À medida que as despesas com os itens essenciais declinam, os itens menos essenciais tornam-se acessíveis, o que permite que os domicílios possam mover-se para baixo em suas listas de compras. Em terceiro lugar, as noções mesmas de necessidade e luxo são relativas. Um bem de consumo pode ser um luxo numa casa pobre, mas um bem altamente necessário num domicílio rico. À medida que a renda de um domicílio cresce, um bem de consumo pode mudar de um bem de luxo para uma amenidade e, finalmente, para um bem necessário. [...] A compra de um bem pelos domicílios de alta renda reduz seu preço, o que torna esse bem acessivel aos domicílios de renda mais baixa que anteriormente não eram capazes de adquiri-lo. Esse processo de escorregamento dos bens ajuda a indústria a decolar. A compra do bem pelos domicílios de renda baixa, ao empurrar o preço ainda mais para baixo, ajuda a reduzir a despesa dos domicílios de renda mais alta, permitindo que eles se movam para baixo em direção ao próximo item de sua lista de compras. Através desse processo, os ganhos de produtividade em uma indústria levam a ganhos de produtividade nas indústrias seguintes. ${ }^{5}$ 
Assim a evolução da economia do ponto de vista dos bens de consumo depende crucialmente da distribuição de renda. Alguma desigualdade é funcional para iniciar o processo quando a renda ainda é baixa, com os mais ricos adquirindo bens ainda caros, visto que produzidos em pequena escala. Mas a desigualdade excessiva e/ou prolongada impedirá o processo de se expandir em novas ondas de consumo. Portanto, a concentração inicial precisará ser no mínimo atenuada para que o processo tenha continuidade no longo prazo.

Podemos observar tais ondas no caso norte-americano. Nos anos 1920, tivemos a expansão de alguns bens de consumo duráveis entre a alta classe média: geladeiras, máquinas de lavar, automóveis (os menos difundidos) ${ }^{6} \mathrm{e}$ rádios (os mais difundidos). Segundo Robertson (1967, p. 675), entre 1920 e 1929, as vendas de aparelhos elétricos pularam de 100 milhões para 543 milhões de dólares - 80\% dos quais decorrentes das vendas de rádios. A partir do final da II Guerra Mundial, esse consumo se espalhou entre as camadas de renda mais baixa, acompanhado de novos bens como aparelhos de ar-condicionado, lavadoras de pratos e, acima de tudo, televisores (Cohen, 2003). Um elemento essencial para a expansão do consumo foi a difusão do crédito entre os mais pobres. A partir da década de 1990, tivemos uma nova onda, com a difusão de computadores e bens de consumo de última geração - veículos e eletrodomésticos poupadores de energia.

Um processo assemelhado ocorreu no Brasil, desde a década de 1950, quando ainda restrito aos mais ricos. O consumo de duráveis teve início nos anos 1940 e 1950, ainda com operações à vista. Ocorreu uma expansão durante o período do milagre econômico, já então lubrificado pelo crédito. Após longo período de incerteza causado pela alta inflação, a estabilização com o Plano Real trouxe um retorno do consumo de duráveis, em parte porque a abertura às importações proporcionou a redução de preços que tornou bens mais acessíveis. Quando, a partir de 2003, tivemos a aceleração de um processo de distribuição de renda e a expansão do crédito, o trickle-down deslanchou.

Vejamos em maior detalhe esse período de moeda relativamente estável com distribuição de renda. Ainda que se deva dar algum peso às políticas sociais focadas nos mais pobres, o mais importante aqui parece ter sido o aumento do salário mínimo real, que subiu ininterruptamente a partir de 1994 e aproximou-se de seu maior valor histórico, alcançado no final dos anos 1950 e início dos anos 1960.

Caso os padrões de consumo das diferentes camadas da população fossem idênticos, o aumento do consumo dos diversos bens seria homogêneo. No entanto, isso não acontece, já que os padrões culturais das diferentes camadas da população são distintos. Todos buscam o padrão de vida da classe média, definido pelas práticas da classe média alta, mas a percepção que têm desse padrão e sua capacidade de alcançá-lo é imperfeita e viesada.

Com a ascensão, aparecem novas necessidades, mas as pessoas/famílias que ascendem socialmente têm um padrão de consumo nitidamente diferente do das camadas que já eram superiores - e, em muitos casos, nitidamente inferior:

\footnotetext{
No âmbito educacional, seus componentes apenas têm acesso a escolas públicas ou particulares com mensalidades mais baixase de qualidade, no mínimo, duvidosa. Na saúde, se não contarem com um plano corporativo decente, dependem da rede pública deteriorada ou de planos de saúde baratos e precários. $E$ essa precariedade estrutural reproduz-se na habitação, transporte, segurança, alimentação, cultura, lazer, entretenimento e em todos os demais aspectos que efetivamente definem as condições de vida. (Quadros, 2010, p. 4)
} 


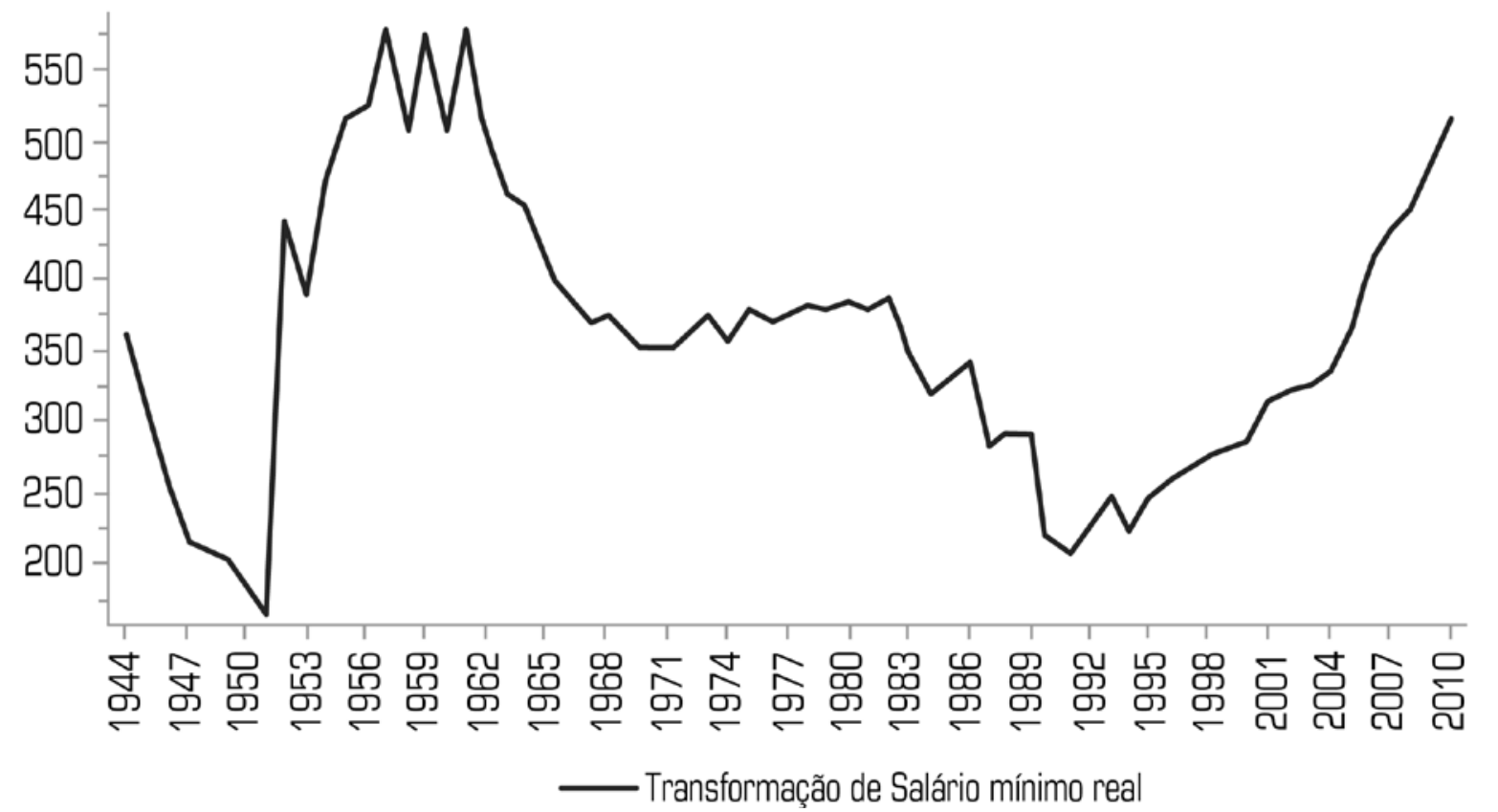

Fonte: Ipeadata.

Tal precariedade em nada foi modificada com o processo aqui em foco, mas a corrida aos bens duráveis serve para atenuar parcialmente a situação de carência. Aí temos a ação de dois mecanismos. De um lado, o efeito-demonstração, que se expressa na busca de alguns bens especiais, percebidos como característicos do consumo das faixas superiores. Aí se incluíram os aparelhos de DVD, os MP3 players, os computadores pessoais, etc. Nesse grupo em particular, nenhum produto teve maior apelo do que o telefone celular, merecendo destaque, em seguida, os demais eletrodomésticos - sempre que a faixa de renda impossibilite a compra de um veículo. De fato, em 1995, existia 1,4 milhão de assinantes de celular, número que aumentou para 174 milhões em 2009, registrando-se aumento de $12.429 \%$.
O outro mecanismo de estímulo ao consumo é a oferta de crédito, ainda que a taxas de juros acima dos $50 \%$ ao ano. $\mathrm{O}$ crédito dirige-se essencialmente aos bens de consumo duráveis. ${ }^{7}$ Desta forma, direciona-se o consumo dos grupos ascendentes para a aquisição dos bens tidos como “indispensáveis ao conforto doméstico nas condições contemporâneas de vida” (Quadros, 2008, p. 4).

$\mathrm{O}$ aumento da renda e do crédito possibilitaram a expansão e o fortalecimento da classe média, criando nesse nível um estrato robusto que o país até então desconhecia. No escopo deste artigo, não faz evidentemente sentido discutir o conceito de classe média, desde sempre um problema para os sociólogos. Para nossos propósitos, basta indicar que se trata de um grupo social que não se reconhece nem 


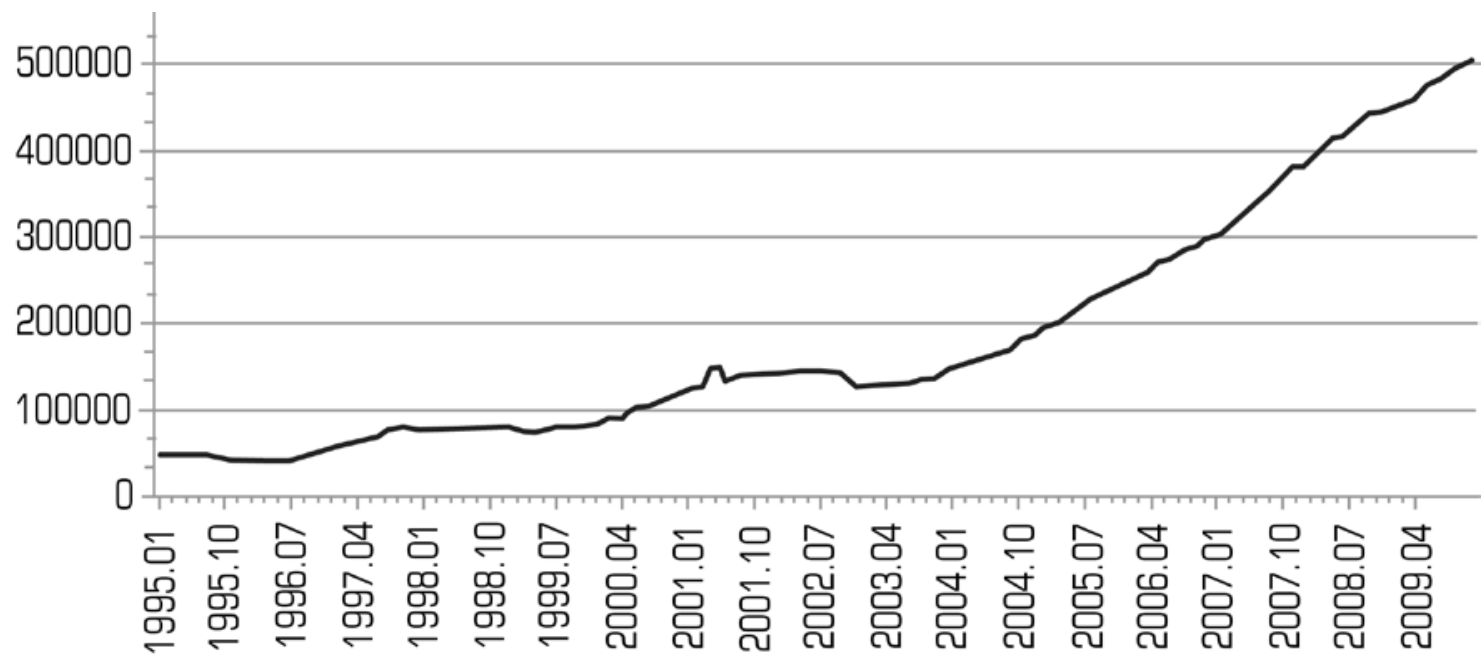

— Operação de crédito ao setor privado - pessoas físicas [deflator:IPCA centrado no final de mês (preços jun. २011 = 1)]

Fonte: Ipeadata.

como rico nem como pobre, e que adota padrões de comportamento (inclusive de consumo) que procuram marcar e reforçar sua distinção, sobretudo em relação às camadas mais pobres. E, entre esses padrões de comportamento, está a adoção das novas tecnologias, tanto para uso produtivo quanto para entretenimento.

Nesses termos, o consumo é uma forma de se adquirir/ reforçar distinção social, através da qual alguém declara seu pertencimento a determinado grupo de referência, entra em um dado padrão de conforto e exorciza a pobreza. ${ }^{8}$ Distinção social é um processo de mão dupla, que implica uma identificação do sujeito enquanto tal e seu reconhecimento pelos outros. Pressupõe, portanto, a adoção de comportamentos reconhecidos pelo grupo de referência como critérios de pertinência. Os bens de consumo, mostra Tarschner, servem como suporte para muitos rituais de inclusão e exclusão social.
Existe uma uniformização mundial do consumo, mencionada por Ferguson (2011). Esse fenômeno resulta da constituição de uma cultura de massa produzida e difundida pelas mídias tradicionais e pela internet, que aponta para uma cesta padrão de bens e serviços de consumo, composta de bens não duráveis (como roupas de grife, calçados esportivos e fast-food), uma infinidade de duráveis, entre eles veículos (automóveis e motos) e eletrônicos (liderados pelo telefone celular e pelo computador) e, finalmente, determinados tipos de serviços, como viagens de turismo. Taschner observa que, em alguns setores, aparece um efeito trickle down - começa pelas camadas de renda mais alta e vai se difundindo progressivamente para as camadas médias e pobres, processo viabilizado pela redução de preços.

Assim, ao que assistimos no Brasil recentemente foi um aumento do consumo de massas voltado para tal cesta padrão, que inclui, como vimos, todo tipo de novos eletro- 
Tabela 2_Percentual das famílias que possuem alguns bens duráveis, por classe de renda familiar (em salários mínimos)

\begin{tabular}{|c|c|c|c|c|c|}
\hline $\begin{array}{l}\text { Faixa de } \\
\text { renda }\end{array}$ & Ano & Televisão & $\begin{array}{l}\text { Conjunto } \\
\text { de som }\end{array}$ & DVD & Automóvel \\
\hline \multirow{2}{*}{ Até 2 s.m. } & 2008-9 & 86 & 36 & 42 & 5 \\
\hline & 1996 & 81 & 33 & - & 4 \\
\hline \multirow{2}{*}{$\begin{array}{l}\text { Mais de } \\
2 \text { a } 3 \text { s.m. }\end{array}$} & 2008-9 & 94 & 45 & 55 & 13 \\
\hline & 1996 & 87 & 49 & - & 8 \\
\hline \multirow{2}{*}{$\begin{array}{l}\text { Mais de } \\
3 \text { a } 5 \text { s.m. }\end{array}$} & 2008-9 & 96 & 52 & 64 & 26 \\
\hline & 1996 & 93 & 54 & - & 12 \\
\hline \multirow{2}{*}{$\begin{array}{l}\text { Mais de } \\
5 \text { a } 6 \text { s.m. }\end{array}$} & 2008-9 & 97 & 57 & 73 & 38 \\
\hline & 1996 & 95 & 55 & - & 19 \\
\hline \multirow{2}{*}{$\begin{array}{l}\text { Mais de } \\
6 \text { a } 8 \text { s.m. }\end{array}$} & 2008-9 & 98 & 61 & 75 & 52 \\
\hline & 1996 & 97 & 68 & - & 24 \\
\hline \multirow{2}{*}{$\begin{array}{l}\text { Mais de } \\
8 \text { a } 10 \text { s.m. }\end{array}$} & 2008-9 & 97 & 63 & 80 & 61 \\
\hline & 1996 & 97 & 65 & - & 32 \\
\hline \multirow{2}{*}{$\begin{array}{l}\text { Mais de } \\
10 \text { a } 15 \text { s.m. }\end{array}$} & 2008-9 & 98 & 64 & 81 & 73 \\
\hline & 1996 & 98 & 74 & - & 46 \\
\hline \multirow{2}{*}{$\begin{array}{l}\text { Mais de } \\
15 \text { a } 20 \text { s.m. }\end{array}$} & 2008-9 & 99 & 65 & 86 & 83 \\
\hline & 1996 & 98 & 79 & - & 59 \\
\hline \multirow{2}{*}{$\begin{array}{l}\text { Mais de } \\
20 \text { a } 30 \text { s.m. }\end{array}$} & 2008-9 & 99 & 70 & 87 & 84 \\
\hline & 1996 & 99 & 81 & - & 74 \\
\hline \multirow{2}{*}{$\begin{array}{l}\text { Mais de } \\
30 \text { s.m. }\end{array}$} & 2008-9 & 97 & 74 & 89 & 88 \\
\hline & 1996 & 99 & 83 & - & 86 \\
\hline
\end{tabular}

Fontes: Taschner (2009) e IBGE/POF, nossa elaboração.

domésticos, veículos (novos e usados), serviços de turismo, celulares e Internet. Na Tabela 2, selecionamos quatro produtos dessa cesta para ilustrar essas mudanças.
A televisão é o mais tradicional desses produtos, pois já em 1996 estava amplamente difundida, visto que até mesmo nas famílias com renda inferior a dois salários mínimos era encontrada em $82 \%$ das residências, índice que subiu para 86\% em 2008-9..$^{9}$ O DVD foi um dos novos bens de consumo introduzidos no mercado de massa, no século XXI, e em 2008-9 estava presente em $42 \%$ das residências com renda inferior a dois salários mínimos e 55\% daquelas entre dois e três salários mínimos. $\mathrm{O}$ conjunto de som é o produto que está caindo em desuso: sua posse cai em todas as categorias, exceto entre os mais pobres. Finalmente, o automóvel apresentou expansão em todas as categorias está presente em mais de metade das residências de famílias com renda acima de seis salários mínimos, e em mais de $25 \%$ daquelas entre três e seis salários mínimos.

Ao mesmo tempo em que o padrão de consumo de bens apresentava esse tipo de mudança, apareciam novos espaços para troca de experiências entre as pessoas, como veremos a seguir.

\section{3_Mudanças no espaço público de sociabilidade}

Aqui cabe recurso a uma analogia com um processo de aumento e diversificação do consumo de bens culturais ocorrido na Inglaterra às vésperas da Revolução Industrial. ${ }^{10} \mathrm{Du}$ rante o século XVIII, aquele país passou por um processo de crescimento da renda associado à introdução de inovações na agricultura, ao crescimento da manufatura e à extensão das suas redes de comércio internacional, mediante sobretudo as companhias privilegiadas. Em paralelo, desenvolveram-se novas ideias e novas formas de consumo cultural e de entretenimento.

No campo das ideias, temos o surgimento da mecânica newtoniana, que não era difundida nas universidades, então dominadas pelo clero da Igreja anglicana e fechadas aos 
adeptos de outras conversões. ${ }^{11}$ Havendo grande curiosidade do público por aquela nova ciência, apareceram professores que proferiam conferências, ministravam cursos livres e vendiam manuais aos interessados. O local para tais eventos eram os novos cafés (coffee houses), que proliferaram rapidamente em paralelo ao aumento da oferta da nova bebida importada.

Os cafés eram a ponta mais elitizada das casas de comércio de bebidas, que incluíam as cervejarias, as tavernas e as casas de gin. Os cafés se distinguiam por cobrarem um ingresso aos frequentadores (no valor de um penny), o que representava uma barreira à entrada de pobres no recinto. Uma vez lá dentro, era livre o acesso aos jornais (que começavam a ser publicados naquela época e eram distribuídos apenas aos assinantes) e aos demais frequentadores. Também era possível alugar salas em seu interior para negócios, palestras, cursos ou meras reuniões entre amigos. Entre as centenas de cafés que proliferavam, deu-se logo uma especialização de público, conforme o estabelecimento ficasse na vizinhança da área de negócios da City, da Academia Real, da Sociedade Geográfica, do Parlamento, do porto, etc. No século seguinte, esses estabelecimentos evoluíram para se transformarem nos famosos clubes ingleses, onde se reuniam homens de classe média que se identificavam em torno de um interesse político ou cultural comum.

Em meio ao movimento cultural sediado nos cafés, difundiu-se o consumo de novos bens culturais. Professores vendiam os livros que acompanhavam seus cursos, o que foi possibilitado pela difusão das gráficas (pelas economias de escopo que essas tinham ao publicarem jornais e pela capacidade ociosa daí decorrente), bem como pela concorrência entre essas, reduzindo os preços da edição de livros. Romances populares se beneficiaram e progressivamente se criou um intermediário entre livro e jornal, o folhetim - um romance publicado no jornal, em capítulos, e que pos- teriormente era impresso no formato livro. Reportagens sobre crimes e escândalos podiam ter o mesmo destino.

Mas o movimento não se resumiu à indústria editorial. Artistas como Hogart se encontravam em seus cafés para discutirem estética e travarem contato com possíveis compradores. ${ }^{12}$ As tavernas (Inns) se diferenciavam por venderem vinhos e oferecerem hospedagem. Homens de renda mais baixa frequentavam as cervejarias, e os pobres se reuniam nas casas de gim - estabelecimentos que não cobravam ingressos e vendiam bebidas mais baratas. Mulheres encontradas em tais estabelecimentos eram frequentemente associadas à prostituição (Soares, 2007).

Em suma, o que se observa no século XVIII inglês é que, com o crescimento da renda, se verificou aumento da oferta de espaços públicos de sociabilidade, que passaram a ser frequentados por camadas amplas da população, em contraposição ao que ocorria no espaço privado das residências. Anteriormente, os espaços públicos estavam limitados às feiras, às tavernas e às igrejas, e o acesso era livre. A partir de determinado momento, apareceram os novos espaços de acesso restrito aos pagantes, originando uma segmentação dos espaços públicos. Nos espaços de livre acesso, ocorria uma socialização interpessoal; nos de acesso restrito, os cafés, além da socialização interpessoal, sucedia o consumo de bens culturais laicos, como jornais, palestras e cursos, em detrimento do consumo cultural de cunho religioso praticado nas igrejas.

Esse processo decorre da incorporação de algumas inovações relevantes e bastante conhecidas na literatura, que aqui listaremos de maneira não exaustiva. Em primeiro lugar, temos um vigoroso processo de urbanização, impulsionado pelo processo de cercamento dos campos, que joga nas cidades contínuas levas de mão de obra barata. $O$ mesmo cercamento deu origem ao segundo fenômeno, na medida em que permitiu a introdução de inovações técni- 
cas no campo, tanto na agricultura como na indústria nascente (que fugia das restrições legais impostas nas cidades pelas corporações de ofício). Em particular, destacam-se duas consequências desse movimento: o crescimento da renda agrícola e o fortalecimento de uma classe média rural (Lawrence, 2008). Em terceiro lugar, temos a criação do império, sobretudo através da atuação de companhias monopolistas de comércio ultramarino, o que, por sua vez, gerou aumento da renda urbana e o fortalecimento de uma classe média (tanto nas cidades como além-mar), proporcionando um mercado crescente para os novos produtos introduzidos (Ferguson, 2010). Entre esses novos produtos, estava o café, adotado, quando de sua introdução, como bebida cara, de consumo restrito às camadas de renda mais alta, consumido em estabelecimentos exclusivos. Finalmente, temos a criação da imprensa, inicialmente para divulgar notícias ligadas ao comércio internacional, e logo estendida ao debate político. Uma externalidade do aparecimento dos jornais foi a difusão de equipamentos de impressão e o barateamento da produção de livros, aproveitando a capacidade ociosa das gráficas.

Tudo sugere que um fenômeno de escopo semelhante esteja ocorrendo no Brasil a partir da estabilização da moeda, alcançada em 1994. Em analogia com o processo de urbanização do século XVIII, que propiciava acesso aos espaços públicos de sociabilidade instalados nas cidades, assistimos à implantação e à difusão da internet, propiciando acesso a um espaço de sociabilidade "virtual", até certo ponto independente de onde o usuário esteja localizado. Para isso é necessário ter acesso aos equipamentos (computadores e celulares) e a uma rede de comunicação. ${ }^{13}$ Esses instrumentos se difundiram no Brasil na última década, como pode ser visto pelos dados das PNADs:

Durante o período de 2003 a 2009, o número de brasileiros com acesso a computador no domicílio subiu de 26 para 69 milhões de pessoas, e aqueles com acesso à internet doméstica passaram de 19 para 54 milhões. $O$ mais interessante para nosso argumento é que o maior salto ocorreu entre

Tabela 3_Moradores residentes em domicílios com computador e telefone, 2003 e 2009, segundo a faixa de renda (milhares)

\begin{tabular}{|c|c|c|c|c|c|c|c|c|}
\hline & $\begin{array}{l}2003 \\
<10 \mathrm{sm}\end{array}$ & 10 a $20 \mathrm{sm}$ & $\begin{array}{l}2003 \\
>20 \mathrm{sm}\end{array}$ & $\begin{array}{l}2003 \\
\text { total }\end{array}$ & $\begin{array}{l}2009 \\
<10 \mathrm{sm}\end{array}$ & $\begin{array}{l}2009 \\
10 \text { a } 20 \mathrm{sm}\end{array}$ & $\begin{array}{l}2009 \\
>20 \mathrm{sm}\end{array}$ & $\begin{array}{l}2009 \\
\text { total }\end{array}$ \\
\hline \multicolumn{9}{|l|}{ Computador } \\
\hline tinham & 11579 & 7885 & 5390 & 26157 & 50181 & 10310 & 4449 & 68949 \\
\hline com internet & 7031 & 6341 & 4901 & 19327 & 36696 & 9470 & 4031 & 53640 \\
\hline não tinham & 134942 & 6286 & 1334 & 147042 & 116248 & 1695 & 223 & 122322 \\
\hline \multicolumn{9}{|l|}{ Telefone } \\
\hline tinham & 81371 & 13772 & 6676 & 105402 & 139064 & 11963 & 4671 & 162626 \\
\hline só celular & 17529 & 922 & 198 & 19201 & 77175 & 1838 & 392 & 81832 \\
\hline só fixo & 34697 & 2228 & 375 & 38379 & 7320 & 188 & 32 & 7905 \\
\hline Celular + fixo & 29145 & 10622 & 6103 & 47822 & 54569 & 9937 & 4247 & 72889 \\
\hline não tinham & 65128 & 399 & 48 & 67774 & 27365 & 40 & 0 & 28345 \\
\hline
\end{tabular}

Fonte: IBGE/PNAD. 
aqueles com renda inferior a 10 salários mínimos, entre os quais os possuidores de computador passaram de 12 para 50 milhões, e aqueles com internet doméstica, de 7 para 37 milhões. ${ }^{14} \mathrm{~A}$ isso se deve acrescentar a expansão da banda larga, que ocorreu a partir de 1999, quando existiam cerca de 100 mil assinantes. Em 2009, já eram 11.400 mil assinantes, em sua quase totalidade, porém, os de renda mais alta. (Associação Brasileira de TV por Assinatura - ABTA, 2010)

Já o número de moradores que habitavam em domicílios que contavam com telefones celulares (incluindo os que tinham também telefone fixo) aumentou de 67 para 155 milhões. Apenas 36 milhões não tinham acesso a celulares em 2009 (o que não deixa de ser um número expressivo, considerando que tal tipo de bem se universalizou nesse período). Mais uma vez, a grande mudança se dá no estrato de renda inferior a 10 salários mínimos: o número de pessoas com acesso a celulares nessa faixa de renda praticamente triplica, passando de 47 para 132 milhões, entre 2003 e 2009. Para aquilo que aqui nos concerne, a importância desse movimento está em que o uso desses aparelhos para lazer difundiu-se rapidamente, compondo assim o caldo de mudança no padrão de consumo cultural a que estamos nos referindo.

Podemos, portanto, perceber aí alguns movimentos simultâneos. Primeiro, o deslocamento de uma parcela substantiva do entretenimento do espaço público para o espaço privado, com o deslocamento do consumo de filmes da sala de cinema para a residência, através de TV e DVDs. Segundo, o surgimento de um espaço público de sociabilidade virtual, a internet, em que o contato pessoal é intermediado pelo meio eletrônico, por meio de redes sociais e comunidades virtuais. ${ }^{15}$ Terceiro, o uso da internet para difusão de conteúdos variados, inclusive músicas e filmes pirateados, em detrimento das redes de comercialização estabelecidas. Quarto, o deslocamento do uso do tempo livre para essas novas atividades, o que implicou a redução do consumo de livros, CDs e de ingressos em salas de cinema.

Tais fenômenos podem ser explicados de diferentes maneiras. Mas existe algo em comum em todos eles: o deslocamento da preferência para um novo suporte do bem cultural - algum meio eletrônico de preço relativamente baixo, que se presta à apropriação privada (em alguns casos com o recurso ao crédito), cuja posse confere prestígio e uma identidade tida como contemporânea. Merece especial destaque a participação em redes sociais: Orkut, Twitter e Facebook, entre outras de menor expressão, funcionam como mídias integradoras de pessoas com os interesses mais variados. ${ }^{16}$

Participação em redes sociais toma tempo, e muito; em troca, confere prestígio. Somado às demais formas de consumo propiciadas pelos novos suportes, sobra muito menos tempo do que antes para as atividades de entretenimento tradicionais. Esse é um fenômeno geral, ao qual se somam causas específicas a cada um dos mercados de bens culturais que analisamos na sequência.

\section{4_A queda no consumo dos bens culturais tradicionais: causas específicas}

Cada um dos bens culturais cujo consumo foi reduzido tem características peculiares a seu mercado, em função da introdução de um ou mais bens substitutos. No caso do cinema, trata-se sobretudo da difusão de outros suportes para assistir a filmes, à TV por assinatura e ao DVD. No caso do livro, o novo suporte para a leitura são os computadores alimentados pela internet banda larga. No caso da música, é igualmente a banda larga, que alimenta computadores, aparelhos de MP3 e telefones celulares. 


\section{1_0 cinema e 0 aumento do consumo de novos suportes}

Dos três bens culturais que aqui analisamos, o consumo do cinema (no sentido da frequência a salas de exibição) foi quem teve a menor perda relativa. É o único cujo consumo apresenta em 2009 pequeno aumento em relação a $1995 .{ }^{17}$ No entanto, ao longo do período, este valor é sistematicamente menor do que o de 1995, exceto em 2003 e 2004, anos em que o número de ingressos vendidos aumentou muito. ${ }^{18} \mathrm{O}$ preço dos ingressos não parece ter tido nenhuma influência a partir de 2000, quando apresentou uma trajetória estável.

A mudança parece encontrar explicação na proliferação de produtos substitutos à frequência de salas de exibição: a TV por assinatura e o DVD, ambos consumidos no âmbito doméstico.

Pesquisa publicada pelo Instituto Datafolha (2008), nos dez maiores mercados de cinema do país, ${ }^{19}$ mostra que $93 \%$ dos entrevistados assistem a filmes, mas apenas $41 \%$ o fazem também em salas de cinema; os demais se utilizando exclusivamente de TV e DVD:

Tabela 4_Suporte em que os entrevistados assistem a filmes

\begin{tabular}{|c|c|}
\hline Suporte & $\%$ \\
\hline DVD + TV & 39 \\
\hline Cinema + DVD + TV & 38 \\
\hline Só TV & 10 \\
\hline Só DVD & 3 \\
\hline Cinema + DVD & 2 \\
\hline Cinema + TV & 1 \\
\hline Total & 93 \\
\hline
\end{tabular}

Fonte: Datafolha (2008).

Gráfico 5_Consumo do bem cultural Cinema $(1995=100)$

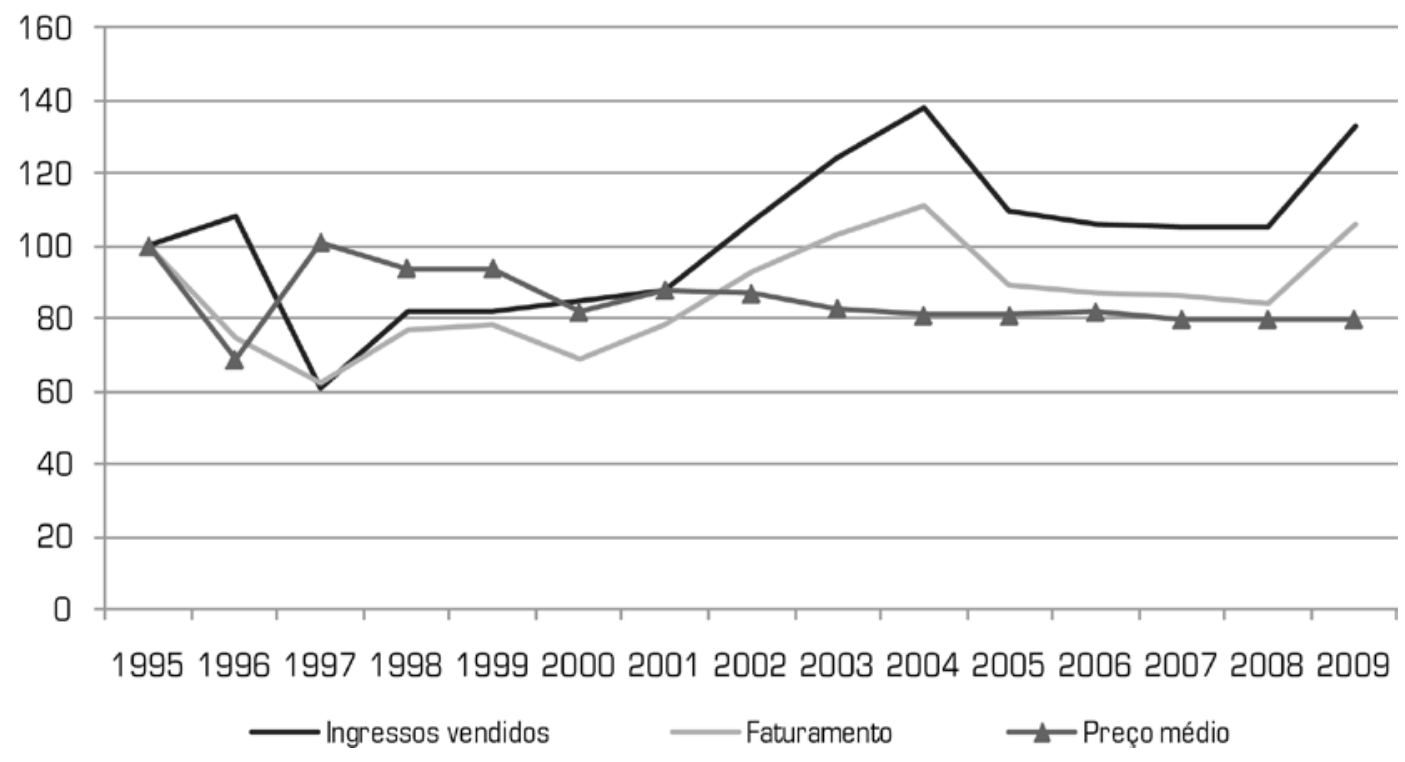

Fonte: Dados: Filme B, nossa elaboração. 
Os resultados da pesquisa mostram o previsível: o principal suporte para assistir a filmes é a TV, utilizada para tal finalidade por $88 \%$ dos entrevistados (sendo que $24 \%$ do total assistem a filmes em TV por assinatura). No entanto, o que surpreende é que assistir a filmes em DVD seja um hábito de $82 \%$ do mesmo público, indicando difusão muito rápida desse suporte.

\subsection{1_0 caso da TV por assinatura}

A Associação Brasileira de Televisão por Assinatura (ABTA) dispõe de uma série estatística com a evolução do número de assinantes, que mostra que o consumo de TV por assinatura legal aumentou 750\%, no período 1995-2009, passando de menos de um milhão para 7,4 milhões de residências. A isso se deve acrescentar a difusão do gatonet, de impossível quantificação, mas com impacto seguramente não desprezível sobre os bens substitutos.

Pode-se avaliar a importância desse veículo para o consumo de filmes a partir de alguns números. Primeiro, as empresas distribuidoras colocam nas salas de cinema brasileiras cerca de 320 títulos/ano, enquanto apenas a NET coloca no ar 2.000 títulos/mês - muitos dos quais feitos especialmente para TV. Outro dado relevante é a evolução da receita: no período 2001-2009, o faturamento real das assinaturas legais aumentou $139 \%{ }^{20}$

\subsection{2_O DVD}

Esta foi a grande novidade introduzida após a estabilização da moeda, que se difundiu no Brasil por todas as faixas de renda, a partir de 2002, trazendo dinamização do mercado de vídeo doméstico, antes restrito ao VHS. O DVD permite transmissão de muito maior qualidade do que o VHS, entre outras razões, porque, com o uso, não sofre o mesmo desgaste que a fita de vídeo.
O gasto da população com DVD é o somatório dos gastos com os aparelhos, com o aluguel de DVDs e com a compra de discos de DVD legais e ilegais. A receita das distribuidoras com vendas de DVDs em 2008 foi um pouco superior àquela registrada nas bilheterias dos cinemas. Quanto ao movimento da pirataria, não existem sequer estimativas confiáveis.

A demanda por compra e aluguel de filmes em suporte DVD é função de dois tipos de preços: o de aquisição do DVD Player e o de aluguel ou de compra do próprio filme. Tal equipamento foi um dos eletrônicos beneficiados pela expansão do crédito ao consumo, e os preços dos diversos modelos caíram drasticamente ao longo dos anos. $\mathrm{O}$ valor de uma prestação mensal de um modelo popular é hoje algo muito próximo ao preço médio do ingresso. Por outro lado, tanto o aluguel de uma fita legal como a compra de uma fita pirata situam-se na mesma faixa de preço da prestação de um modelo popular.

\section{2_0 livro}

Após a estabilização da economia, as famílias aumentaram seu consumo de livros - $10 \%$ a $20 \%$, se medido pelo volume de exemplares, no primeiro governo FHC. ${ }^{21}$ No entanto, entre 1999 e 2003, observou-se uma queda nas vendas da ordem de 50\% (e de 2/3 no caso de didáticos). Esse fenômeno pode ser parcialmente explicado pelo movimento dos preços médios dos livros, que subiram substantivamente ao longo de todo o período 1999-2003.

Esse comportamento de redução das compras em função do aumento de preço é ainda mais claro no caso de livros didáticos.

Mas os preços não explicam tudo. Aparentemente, houve movimentos no sentido de aumento de consumo de bens substitutos. No que se refere ao livro didático, é voz corrente no meio que se difundiram as apostilas e a reciclagem de livros usados (através das feiras de trocas realizadas nos colégios, no início do ano letivo). Em ambos os casos, trata- 
Gráfico 6_Consumo de livros pelo mercado $(1995=100)$

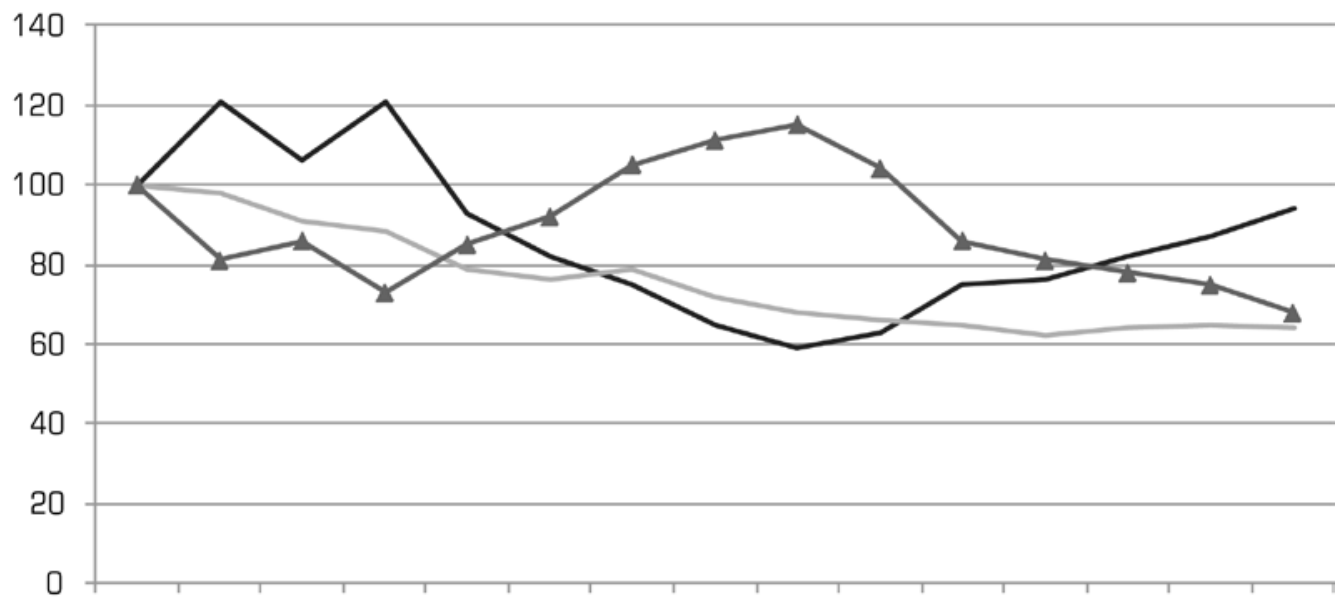

199519961997199819992000200120022003200420052006200720082009

—Exemplares vendidos —-Faturamento —-Preço médio

Fonte: Dados: Pesquisa “Produção e Vendas do Setor Editorial” CBL-SNEL/FIPE, nossa elaboração.

Gráfico 7_Consumo de livros didáticos pelo mercado $(1995=100)$

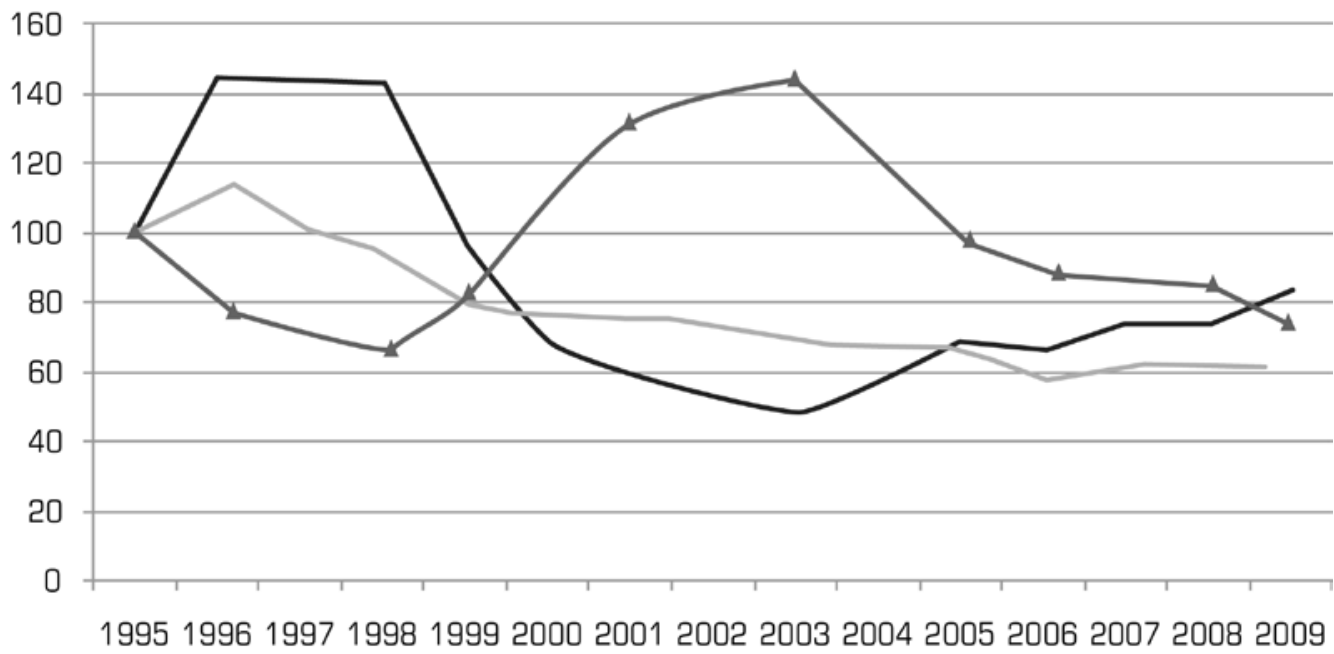

-Exemplares vendidos - Faturamento $\quad$ - Preço médio

Fonte: Dados CBL e FIPE, nossa elaboração. 
-se de bens substitutos inferiores, mas podemos igualmente apontar para a presença de um substituto superior - a internet, principalmente através da absorção de trabalhos prontos e do acesso a instrumentos como a Wikipedia.

Aqui não há indicadores tão sólidos como no caso anterior, mas apenas suspeitas não quantificadas - apostilas, livros usados, pirataria, internet. Para contornar essa dificuldade, podemos recorrer a uma informação indireta, como a da demanda por leitura, que aparece nas pesquisas de Botelho e Fiore e do Instituto Pró-Livro.

Botelho e Fiore (2005) mostram um dado até certo ponto surpreendente, em um país tido como de poucos leitores: 40,5\% dos entrevistados na Região Metropolitana de São Paulo, em 2002, afirmaram terem lido algum livro meramente por prazer, nos 12 meses anteriores. Esse percentual varia na razão direta da renda: é de 54,6\% nas classes A/B, de 41,4\% na classe C, e de $24,9 \%$ nas classes D/E.

A pesquisa do Instituto Pró-Livro mostra que 35\% dos entrevistados gostam de ler (em qualquer suporte, inclusive jornal e revista) em seu tempo livre. Esse índice aumenta para $48 \%$ entre os que completaram o segundo grau, $64 \%$ entre os que completaram o ensino superior e $67 \%$ entre os que ganham mais de 10 salários mínimos.

Esse gosto pela leitura pode ter sido canalizado para um novo suporte, a internet. Ainda que nenhuma pesquisa tenha procurado averiguar esse ponto, a observação das mudanças na vida cotidiana sugere a ocorrência de tal fenômeno na medida em que, com a difusão da banda larga, se reduziu a quase nada o tempo de espera para download de textos. ${ }^{22}$

Um elemento que reforça a hipótese de recurso à internet é o apoio que essa proporciona à chamada "cultura do gratuito" (Andersen, 2008, 2009), ao fato de que segmentos cada vez mais amplos da população têm acesso aos mais diversos produtos sem contrapartida monetária. Nesse caso, incluem-se os mais diversos softwares (Yahoo, Google,
Hotmail, etc.), armazenamento de arquivos, acesso a edições online de jornais e revistas - tudo isso de forma legal. Uma consequência desse movimento foi uma mudança radical na economia dos jornais, com a redução das tiragens e o aparecimento dos diários de distribuição gratuita, financiados apenas por publicidade.

No que se refere aos substitutos dos livros, aparece em primeiro lugar a Wikipedia, que simplesmente liquidou com o mercado de enciclopédias. A isso se acrescenta a grande maioria dos trabalhos acadêmicos, livremente acessíveis àqueles que têm acesso ao portal da Capes, além do acesso praticamente a todos os textos para discussão editados por universidades e centros de pesquisa. A livre distribuição de cópias em formato PDF atinge as publicações de órgãos como IPEA, BNDES e IBGE. Além disso, proliferam os sites piratas de PDFs, como o famoso library. $n u$.

Como destaca Andersen (2009, p. 158), o livro em formato digital difundiu-se de forma relativamente lenta, uma vez que era visto como um bem inferior, na medida em que precisava ser lido em um monitor ou impresso em papel A4. Essa situação começou a mudar radicalmente a partir de 2009, com o aparecimento de suportes digitais confortáveis para o leitor - o Kindle, da Amazon, e os Tablets, liderados pelo iPad. Eliminado o desconforto do monitor, que afastava ao menos as gerações mais velhas, os novos suportes possibilitam aproveitar ao máximo as vantagens do pouco tempo de espera $^{23}$ e do preço mais baixo. Essas inovações colocam o livro no epicentro de uma revolução que agora, em 2011, suscita a discussão de novos modelos de negócios, que podem mudar radicalmente o perfil do setor nesta próxima década.

\section{3_A música}

Este é o caso mais grave de queda nas vendas de um produto cultural: a receita com as vendas de música gravada em 2009 atingiu 13\% do que havia sido em 1995. Podemos 
Gráfico 8_Faturamento da indústria da música gravada (1995 = 100)

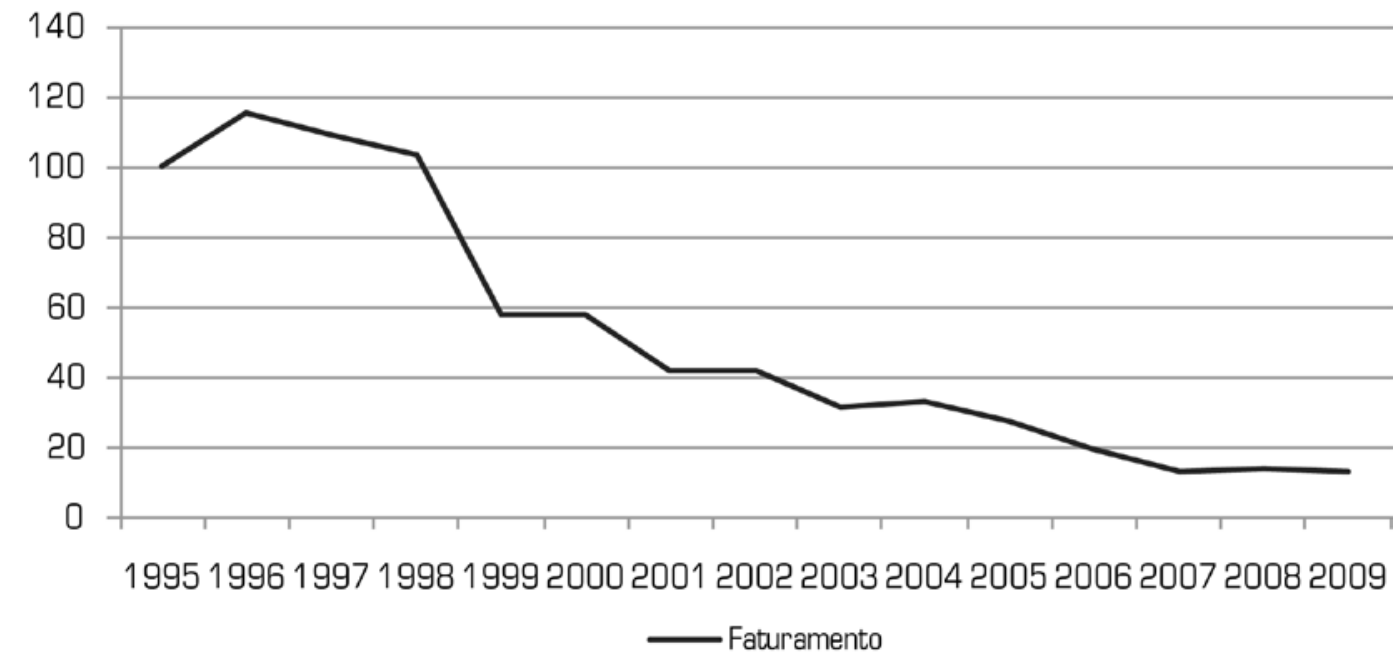

Fonte: ABPD.

relacionar esse fenômeno a fatores ligados tanto à demanda como à oferta.

A razão, da ótica da demanda, é principalmente a difusão da prática de distribuição de arquivos musicais através da internet, o que deu ao produto a característica de bem livre. Como nota Andersen (2009, p. 148), ao contrário do livro, o suporte digital não traz desconforto ao consumidor de música, antes amplia suas possibilidades, já que um receptor MP3 ou um iPod tanto podem ser conectados a um amplificador como acompanharem seu usuário a todos os lugares sem perda de qualidade sonora. Assim, a transição de um CD para o suporte digital significou a migração para um bem superior, o que foi rapidamente percebido pelo mercado, na medida em que as vendas de fonogramas em suporte físico desabaram.

Olhando sob o ponto de vista da oferta, Matos (2008, p. 16) afirma que a introdução das inovações ligadas à digitalização da indústria de música gravada afetou a estrutura produtiva de diversas formas:

\begin{abstract}
O modelo de organização da indústria estabelecido mostra sua sustentabilidade ameaçada por três fatores correlacionados: a possibilidade de se produzir as gravações e o produto físico a custos decrescentes; o uso da internet e outras redes de comunicação para exercer a atividade de distribuição da música e para transmissão da música; e a crescente pirataria, que emerge dos fatores anteriores, afetando a venda de fonogramas e dificultando a exploração dos direitos de propriedade intelectual. ${ }^{24}$
\end{abstract}

A redução de custos da gravação contribuiu para a redução dos custos das gravadoras, mas levou igualmente a acabar com seu poder oligopólico sobre a produção de fonogramas. Isso porque não apenas os artistas passaram a poder realizar suas gravações com um equipamento doméstico, como os piratas passaram a ter a possibilidade de reproduzir tais fonogramas a um custo muito baixo 
A pirataria pode ser rapidamente historiada em algumas fases. Inicialmente, nos anos 1980, as gravações ainda eram feitas em grandes estúdios, portanto caras e fora do alcance de artistas isolados. Na mesma época, porém, era fácil reproduzir tais fonogramas usando como suporte as fitas cassete. Foi por onde a pirataria começou, tão logo caiu o preço dos aparelhos toca-fitas, inundando as calçadas e os camelódromos de todos os países de justiça leniente. Nos anos 1990, tanto a gravação como a cópia de CDs se difundiram, logo que baratearam os aparelhos de gravação e os CD Players. Assim se difundiram cópias ilegais não apenas de fonogramas, como de software e de filmes.

Mas a grande transformação ocorreu com o barateamento dos computadores e celulares, acompanhado pelo surgimento dos aparelhos de MP3 e, já no século XXI, da banda larga. A partir de então, a transferência ilegal de fonogramas deixou de ser feita por criminosos, com a finalidade de auferir receitas à margem da lei, e passou a ser feita por cidadãos comuns, pela internet, sem qualquer objetivo econômico, pelo simples prazer da divulgação.

A partir dessas mudanças, a indústria de música gravada em suporte físico entrou em decadência.Ascenderam a música digital, negociada pela internet (modelo iTunes) e a música distribuída gratuitamente, como amostra grátis, capaz de suscitar tanto a aquisição de CDs e DVDs como o comparecimento a espetáculos ao vivo (Dias, 2008, p. 165-166). A perda de receita das gravadoras fez com que essas reduzissem o número de artistas de seus plantéis e passassem a tentar obter participação nas receitas de seus espetáculos ao vivo.

\section{5_Conclusão}

A queda no consumo de bens culturais no Brasil, após a estabilização da moeda, pode ser explicada por uma mu- dança no padrão de consumo das famílias brasileiras, por alterações em processo nas formas de sociabilidade e também por diversos fenômenos específicos de cada mercado.

A mudança global diz respeito à distribuição de renda, ainda que incipiente, e ao aumento do crédito, que propiciaram a ampliação do mercado de massa para bens de consumo duráveis no país. Foram tais mudanças que aumentaram o consumo de diversos bens de consumo duráveis, entre os quais têm importância especial para a questão aqui discutida aqueles que funcionam como suportes eletrônicos para o consumo de filmes, leitura e música.

Esses novos suportes funcionaram como bens substitutos dos suportes tradicionais - respectivamente exibições em salas de cinema, livros em papel e música gravada em CDs. Como resultado, ainda que tudo indique que o consumo daqueles bens aumentou, as estatísticas existentes não o registram, por estarem voltadas para ilustrar suportes que estão sendo abandonados.

A difusão dos novos suportes, porém, tem impactos que vão muito além do mercado de bens culturais, o que constitui, por si só, um elemento adicional na explicação dos fenômenos aqui estudados. As novas tecnologias, como indicamos, possibilitaram aumento da comunicação multidirecional entre os usuários, que é a grande mudança cultural, com impactos nas formas de sociabilidade, surgida no século XXI. O conjunto de suportes - computadores, celulares, Tablets -, articulados através da internet, configura um novo espaço público, agora virtual, capaz de incorporar em debates um número muito maior de pessoas do que é possível em contatos reais. O impacto político desse novo espaço público pode ser inferido pelo seu papel na chamada “Primavera Árabe", no início de 2011, sendo provável que ainda venham a aparecer muitas inovações nesse campo. ${ }^{25}$ As possibilidades econômicas apenas se esboçam, em fenômenos como a redução dos mercados 
para venda de jornais (substituídos pelos gratuitos e pela internet) e pelas diversas formas de interatividade entre jornais online e programas de televisão e seu público.

Em meio a um conjunto de dúvidas diante do novo cenário, é possível adiantar duas conclusões, ainda que precárias. A primeira é que os economistas têm diante de si ampla fronteira de expansão, cuja avaliação exigirá a construção de instrumentos teóricos cuja extensão ainda nos escapa. A segunda é que a população brasileira corre para aproveitar as possibilidades do novo continente, o que foi propiciado por uma tímida redistribuição de renda e um processo incipiente de constituição de um mercado de massa para tais suportes.

Existem dois elementos no atual cenário econômico que afetam tais mudanças. No nível micro, temos dois elementos: (i) a política industrial de substituição de importações dos suportes (no momento em que escrevemos estas linhas, em vias de introduzir o Tablet nacional), com produtos a um custo consideravelmente reduzido e capazes de chegar a um público muito maior; e (ii) a implantação de um programa de banda larga de alta velocidade acessível às massas de baixa renda. No nível macro, os rumos da distribuição de renda, com a continuidade, o aprofundamento ou a atenuação da velocidade atual. Enquanto a mudança micro parece não enfrentar obstáculos de monta, a mudança macro depende do comportamento do eleitorado na próxima década - em boa parte condicionado pelo que ocorrerá no espaço público virtual.

\section{Notas}

${ }^{1}$ Ainda que, em 2009, o valor das vendas de ingressos tenha sido $6 \%$ superior ao valor de $1995 \mathrm{em}$ termos reais, esse é um fenômeno sazonal, que ocorre quando coincidem as estreias de grande número de blockbusters (filmes de grande bilheteria) - o que, no período, só ocorreu em 2003, 2004 e 2009.

${ }^{2}$ Voltaremos a tocar no assunto do aumento do salário mínimo, mas não custa adiantar que ele cresceu, em termos reais, $88,5 \%$ entre dezembro de $1995 \mathrm{e}$ dezembro de 2009, tendo sido esse crescimento composto da seguinte forma: $19,6 \%$, entre dezembro de 1995 e dezembro de 2002, e $57,6 \%$, entre dezembro de 2002 e dezembro de 2009. Essas variações têm por base os dados do Ipeadata, que utilizam o INPC como deflator.

${ }^{3}$ Observe-se que não se encontram os ricos entre os estratos de renda elencados. $\mathrm{Na}$ coleta de dados efetivada pela PNAD, é o entrevistado quem informa sua renda, o que constitui um filtro a valores mais elevados. Estima-se, por isso, que cerca de 90\% dos rendimentos capturados pela pesquisa têm origem nas chamadas "rendas do trabalho" (salários, pensões, aposentadorias, outros benefícios previdenciários, rendas compensatórias e rendimentos de autônomos), sendo apenas $10 \%$ derivados de outras fontes (lucros, dividendos, juros e aluguéis). Como a divisão do valor adicionado bruto entre rendas do trabalho e demais rendas é hoje no Brasil, a julgar pelos dados das Contas Nacionais, grosso modo $50 \%$ para cada um dos dois grupos, pode-se ter uma ideia do montante de renda que a PNAD não captura.

${ }^{4}$ Daqui por diante, os dados sobre renda familiar média ao longo do período serão sempre fornecidos nesse formato: reais de 2009, com deflacionamento da série tendo sido feito pelo INPC calculado pelo IBGE.

${ }^{5}$ Nossa tradução, valendo-se do artigo original de Matsuyama

"The rise of mass consumption societies", publicado no Journal of Political Economy em 2002.

${ }^{6}$ Em 1913, os Estados Unidos produziam 485 mil veículos por ano, pulando para 3,7 milhões em 1925 e 4,4 em 1929. (Prado, 2009, p. 20)

${ }^{7}$ Não temos o crédito dedicado ao consumo de duráveis, mas utilizamos como proxi o crédito às pessoas físicas, que no período após 2002 praticamente quadruplicou.

${ }^{8}$ A sociologia do consumo é campo de ampla controvérsia. Para algumas das principais posições, ver Bourdieu (2009), Ferguson (2011), Taschner (2009) e Bauman (2008).

${ }^{9}$ A grande expansão do consumo deste produto se deu na década anterior a 1996; para exemplificar, em 1987 apenas $45 \%$ das famílias 
com renda inferior a dois salários mínimos tinham televisão, e 60\% daquelas com renda de dois a três salários mínimos (dados de Tarschen, 2009).

${ }^{10}$ As informações sobre esse período histórico que aparecem na sequência estão inteiramente baseadas em Soares (2007).

${ }^{11}$ Durante dois séculos, apenas professores e alunos de fé anglicana tiveram acesso às universidades inglesas.

${ }^{12}$ Este movimento é encontrado igualmente na Paris do século XIX (talvez tendo existido anteriormente). Pelo menos a partir de 1830 , inicialmente na região de Montmartre e posteriormente em Montparnasse e nos bistrôs situados nas imediações das Écoles, verifica-se o mesmo movimento de cafés para discussões filosóficas, políticas e científicas.

${ }^{13}$ Existe aqui, ao que nos parece, leve semelhança com o fenômeno de redução de barreiras espaciais ocorrido séculos atrás, quando apareceu o serviço de correios, só que em tempo real.

${ }^{14}$ Nada de ufanismo, porém: em 2009 ainda existiam cerca de 122 milhões de pessoas sem o conforto do computador doméstico.

${ }^{15} \mathrm{O}$ acesso é restrito aos que podem pagar a quantia simbólica que seja - para acessar a Web. Esse valor é sempre inferior ao preço de um livro ou ao de um $\mathrm{CD}$ e, frequentemente, ao de um ingresso em sala de cinema.

${ }^{16}$ Não se pode esquecer seu papel nas recentes sublevações do mundo islâmico, em países em que a censura e a repressão tinham obstruído a contestação pelos mecanismos tradicionais

${ }^{17}$ Este é o resultado quando deflacionamos a série pelo IPCA; o mesmo não acontece quando deflacionamos pelo IGP-DI, como em Sá-Earp e Sroulevich (2009).

${ }^{18}$ A explicação para este aumento parece estar na coincidência da exibição de um conjunto de blockbusters, dos quais cinco produzidos no Brasil.

${ }^{19}$ Esses 10 maiores mercados são: as regiões metropolitanas do Rio de Janeiro e de São Paulo e as cidades de Campinas,

Belo Horizonte, Curitiba, Porto Alegre, Salvador, Recife, Fortaleza e Brasília.

${ }^{20}$ Este dado inclui receitas de publicidade, mas trata-se de um valor desprezível (inferior a 10\%).

${ }^{21}$ Os valores aqui mencionados referem-se apenas às vendas efetuadas ao mercado, sem incluir aquelas oriundas de compras governamentais. Essas vendas são expressivas no Brasil (constituem hoje praticamente um quarto das vendas totais de livros), mas são determinadas por razões próprias do governo no desenvolvimento da política educacional e de apoio à formação e manutenção de bibliotecas, não devendo, portanto, ser consideradas nos números aqui utilizados.

22 A demora ainda relativamente importante no download de vídeos era uma barreira a consumidores com pouco tempo livre, mas não aos jovens que dispunham de tempo abundante. $\mathrm{O}$ aumento da velocidade da banda larga está mudando dramaticamente tal situação.

${ }^{23}$ Enquanto um livro encomendado em uma livraria digital varia de dois dias (Livraria Cultura, nas grandes cidades brasileiras) a um mês (Amazon ou Barnes and Noble), um e-book tem um tempo de download que não ultrapassa dois minutos.

${ }^{24}$ Ainda que com objetivos diferentes, o trabalho de Guedes Pinto (2011) indica o mesmo fenômeno, além de apresentar elementos que podem igualmente reforçar o argumento em torno da criação de outro espaço público de sociabilidade desenvolvido na segunda seção do presente artigo.

${ }^{25} \mathrm{O}$ que ocorreu de novo foram troca de informações e análises pela população, à margem da grande imprensa e da possibilidade de censura dos governos. As tentativas de censura à internet não foram bem-sucedidas, pelo menos até o momento. 
ABPD - Associação Brasileira de Produtores de Discos (diversos anos). Mercado Brasileiro de Música. Disponível em: <http:// www.abpd.org.br/estatisticas_ mercado_brasil.asp $>$. Acesso em: 10.12.2010

ABTA - Associação Brasileira de TV por Assinatura (diversos anos). Base de Assinantes - Levantamento Setorial Operadoras.

Disponível em: $<$ http:// TVporassinatura.org.br/index. php?option=comcontent $\&$ view $=$ article $\&$ id $=19 \&$ Itemid $=36>$. Acesso em: 21.02.2011

ANDERSEN, Chris. Free! Why $\$ 0.00$ is the future of business. Wired Magazine, vol. 16, n. 3, 2008.

ANDERSEN, Chris. Free: Grátis. $\mathrm{O}$ futuro dos preços. Rio de Janeiro: Elsevier, 2009.

BAUMAN, Zygmunt Vida para consumo. A transformação das pessoas em mercadoria. Rio de Janeiro: Zahar, 2008.

BOTELHO, Isaura; FIORE, Maurício O uso do tempo livre e as práticas culturais na Região Metropolitana de São Paulo. São Paulo: Centro de Estudos da Metrópole do CEBRAP, 2005.
BOURDIEU, Pierre. A economia das trocas simbólicas. São Paulo: Perspectiva, 2009.

CBL - Câmara Brasileira do Livro (diversos anos). Produção e vendas no mercado editorial.

COHEN, Lizabeth. A consumer's republic: The politics of mass consumption in post-war America. Vintage Press, 2003.

DATAFOLHA. Hábitos de consumo no mercado de entretenimento. São Paulo: Instituto de Pesquisas Datafolha. Pesquisa realizada para o Sindicato das Empresas Distribuidoras Cinematográficas do Município do Rio de Janeiro. 2008.

Disponível em: $<$ http://sedcmrj. locaweb.com.br/pesquisa/ pesquisa_habitos_consumo_ agosto2008.pdf $>$ e $<$ http:// sedcmrj.locaweb.com.br/ pesquisa/pesquisa_habitos_ consumo_qualitativa.pdf $>$. Acesso em 28.07.2010
DIAS, Márcia Tosta. Indústria fonográfica: A reinvenção de um negócio. In: BOLAÑO, C.; GOLIN, C.; BRITTOS, V. [Orgs.]. Economia da arte e da cultura. São Paulo: Itaú Cultural, São Leopoldo: CEPOS/USISINOS, Porto Alegre: PPGCOM/UFRGS, São Cristóval: Obscom/UFS. 2010. Disponível em: $<$ http:// www.itaucultural.org.br/ bcodemidias/001719.pdf $>$.

Acesso em: 10.11.2010 OBS.: Não aparece no texto. (referência feita na p. 25)

FERGUSON, Niail. Império. Como os britânicos fizeram o mundo moderno. São Paulo:

Planeta, 2010.

FERGUSON, Niail. Civilization.

The West and the rest. London:

Penguin, 2011.

FILME B (2010). Gráficos e tabelas disponíveis em $<$ http://www. filmeb.com.br/portal/html/ graficosetabelas.php $>$. Acesso em: 18.06.2011

FIPE (diversos anos). Produção e vendas do setor editorial.

\section{GUEDES PINTO, J. P. No}

ritmo do capital: Indústria fonográfica e subsunção do trabalho criativo antes e depois do MP3. Tese (Doutorado em Instituições e Desenvolvimento) - IPE, Universidade de São Paulo, São Paulo, 2011.
IPEA. PNAD 2009: Primeiras análises. Comunicados IPEA $n^{\circ} 63,5$ de outubro de 2010. Disponível em: $<$ http://www. ipea.gov.br/portal/images/ stories/PDFs/

comunicado/101005 comunicadoipea63.pdf. Acesso em: 21.02.2011

INSTITUTO PRÓ-LIVRO (2008). Retratos da leitura no Brasil. Disponível em: $<$ http://www. prolivro.org.br/ipl/publier4.0/ texto.asp?id=1815 $>$. Acesso em: 15.03.2011

JAMES (2008) - ver pág. 15 (trata-se de LAWRENCE, 2008 já arrumei a referência na p. 15)

LAWRENCE, James. The middle class - a history. London: Abacus, 2008. Não aparece no texto (resolvido aparece na p. 15).

MATos, Marcelo G. Música.

Projeto Perspectivas do

Desenvolvimento no

Brasil, bloco Economia do

Conhecimento. Rio de Janeiro/ Campinas: IE/UFRJ e IE/

UNICAMP, 2008.

MatsuYama, Kiminori. The rise of mass consumption societies. Journal of Political Economy, vol. 110, nº 5, 2002. 
PRADO, Luiz Carlos D. A economia política da Grande Depressão da década de 1930 nos EUA: Visões da crise e da política econômica In: LIMONCIC, Flávio; MARINHO, Francisco C. Palomares [Orgs.]. A Grande Depressão. Política econômica na década de 1830 Europa, Américas, África e Ásia. Rio de Janeiro: Civilização Brasileira, 2009.

QUADROS, Waldir. Brasil: Um país de classe média? Le Monde Diplomatique, ano 4, n 40, 2010.

QUADROS, Waldir.

Estratificação social no Brasil: O "efeito demográfico". Texto para Discussão IE/UNICAMP n ${ }^{\circ}$ 151, novembro, 2008.

QUADROS, Waldir. $\mathrm{O}$

comportamento do consumidor de produtos culturais e os combos de entretenimento. In: MELO, Victor A. (Org.). Lazer: Aspectos históricos, configurações contemporâneas. São Paulo: Alínea, 2009a.

ROBERTSON, Ross M. História da economia americana. Rio de Janeiro: Record, 1967.

SÁ-EARP, Fabio; SROULEVICH, Helena. O mercado do cinema no Brasil. In: Politicas culturais: Reflexões e ações. São Paulo: Itaú cultural, Rio de Janeiro: Casa de Rui Barbosa, 2009.

SOARES, Luiz Carlos. Albion revisitada. Ciência, religião, ilustração e comercialização do lazer na Inglaterra do século
XVIII. Rio de Janeiro: 7 Letras, FAPERJ, 2007.

SOUZA, Jessé de. Os batalhadores brasileiros: Nova classe média ou nova classe trabalhadora? Belo Horizonte, Editora UFMG, 2010. Não aparece no texto.

TELEBRASIL. O desempenho do setor de telecomunicações no Brasil - séries temporais $3 \mathrm{~T} 10$. 2010. Disponível em: <http:// www.telebrasil.org.br/saibamais/O_Desempenho_do_ Setor_de_Telecom_-_Series_ Temporais_\%203T10-dez_20_2010. pdf $>$. Acesso em: 28.12.2010

TASCHNER, Gisela. Cultura, consumo e cidadania. Bauru: EDUSC, 2009.

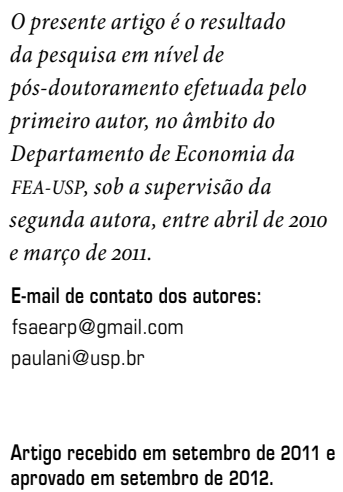

